\title{
Alternative technique for lychee flowering
}

\section{Técnica alternativa para florescimento de lichieira}

\author{
Patrícia Soares Furno FONTES ${ }^{2}$; Alexandre Gomes FONTES ${ }^{2}$; Emilly Lorenzutti BORGHI3; \\ Poliana Daré Zampirolli PIRES²; Leandro Glaydson da Rocha PINHO²; André Assis PIRES ${ }^{2}$
}

${ }^{1}$ Autor para correspondência, Doutora, Instituto Federal de Educação do Espírito Santo Campus Itapina. Departamento de Desenvolvimento Educacional, Coordenação Geral de Ensino, Laboratório de Solos. Br 259, km 70, Itapina, Colatina Espírito Santo, CEP 29709 910. patricia.fontes@ifes.edu.br

2 Doutores, Instituto Federal de Educação do Espírito Santo - Campus Itapina. alexandre.fontes@Ifes.edu.br, poliana.pires@ifes.edu.br, leandro.pinho@ifes.edu.br; andre.pires@ifes.edu.br

${ }^{3}$ Aluna bolsista do CNPq Instituto Federal de Educação do Espírito Santo - Campus Itapina emilylborghi@hotmail.com

Recebido em: 29-08-2013; Aceito em: 30-01-2015

\begin{abstract}
The experiment was conducted in the municipality of Colatina -ES, Brazil, aiming at evaluating the flowering of lychee (Litchi chinensis Sonn.) in response to the girdling of branches of different diameters, located in different parts of the plant canopy and in two seasons, October 2010 and March 2011. The girdling was also carried out in October, as an attempt to extemporaneous production of litchi. As the girdling in October produced no induction of flowering, the final analysis of the experiment outlined in randomized blocks was done in $4 \times 4$ factorial (quadrants $\times$ branches), with four replications and one tree as experimental plot. The girdling in isolated plants consisted of: girdling branches or main branches (8.0 to $10.0 \mathrm{~cm}$ in diameter), girdling branches from 6.0 to $7.9 \mathrm{~cm}$ in diameter, girdling branches with diameters of 4.0 to $5.9 \mathrm{~cm}$, and without girdling (control), located in the southeast, southwest, northeast and northwest quadrants of the plant's canopy. The amount and the length of the inflorescences and the percentage of flowering of lychee were evaluated in light of the girdling of branches and of the location of the quadrants in the canopy of the plants. It was observed that there was a difference between the amount of girdling in the variables for length and amount of inflorescences, while the girdling of branches with 8 to 10 and from $6 \mathrm{~cm}$ to $7.9 \mathrm{~cm}$ in diameter were superior to the control in girdling of branches of 4 to $5.9 \mathrm{~cm}$ diameter. Concerning the position of the branches in the canopy (quadrants) it was discovered that the quadrants receiving less light (southeast and southwest) had more flowers and flowering percentages, but there was no significant difference for the variable length of the inflorescence according to the quadrants. The girdling of the branches can be an alternative to the insertion of hot climates in the production of lychee.
\end{abstract}

Additional keywords: girdling; inflorescence; Litchi chinensis; temperature.

\section{Resumo}

O experimento foi conduzido no município de Colatina -ES, objetivando-se avaliar o florescimento da lichieira (Litchi chinensis Sonn.) em resposta ao anelamento de ramos de diferentes diâmetros, localizados em diferentes quadrantes da copa da planta e em duas épocas: outubro de 2010 e março de 2011. Realizou-se o anelamento também no mês de outubro, como tentativa de produção extemporânea da lichieira. Como o anelamento no mês de outubro não produziu indução de floração, a análise final do experimento, delineado em blocos casualizados, foi feito em esquema fatorial $4 \times 4$ (ramos $\times$ quadrantes), com quatro repetições e uma árvore como parcela experimental. Os anelamentos em plantas individualizadas foram constituídos de: anelamento de ramos ou pernadas principais $(8,0$ a 10,0 cm de diâmetro), anelamento de ramos de 6,0 a $7,9 \mathrm{~cm}$ de diâmetro, anelamento de ramos com diâmetros de 4,0 a 5,9 cm e sem anelamento (testemunha), localizados nos quadrantes sudeste, sudoeste, nordeste e noroeste da copa da planta. Foram avaliados a quantidade, o comprimento das inflorescências e a percentagem de florescimento da lichieira em função dos anelamentos dos ramos e da localização dos quadrantes na copa das plantas. Observou-se que houve diferença entre os anelamentos para as variáveis quantidade e comprimento de inflorescências, sendo que 0 anelamento em ramos de 8 a $10 \mathrm{~cm}$ e de 6 a $7,9 \mathrm{~cm}$ de diâmetro foi superior à testemunha e ao anelamento em ramos de 4 a $5,9 \mathrm{~cm}$ de diâmetro. Para a posição dos ramos na copa (quadrantes), verificou-se que os quadrantes que receberam menor luminosidade (sudeste e sudoeste) apresentaram maiores quantidades de flores e percentagens de florescimento, porém não houve diferença significativa para a variável comprimento de inflorescência em função dos quadrantes. $O$ anelamento dos ramos pode ser uma alternativa para a inserção de regiões de clima quente na produção de lichia.

Palavras-chave adicionais: anelamento; inflorescência; Litchi chinensis; temperatura. 


\section{Introduction}

The lychee (Litchi chinensis Sonn.) is a subtropical fruit of high commercial value due to its attractive red color and white aryl, which is translucent and appreciated for its sweet taste (Zhang et al., 2001; Zhang et al., 2004; Martins, 2005).

The lychee requires dry and cold weather in winter to be induced to flower, and hot and humid weather in the rest of the year. Production alternation is a characteristic of some lychee varieties, which is more pronounced when grown in warm climates. According to García-Pérez \& Martins (2006), the lychee requires seasonal temperature variations for best flowering and fruiting. Most varieties need a cold period of 100 to 200 hours between 0 and $7^{\circ} \mathrm{C}$, preferably with low rainfall. There is evidence that lower night temperatures below $15^{\circ} \mathrm{C}$ during autumn favor floral induction, and high daytime temperatures at the same period reduce low temperatures effectiveness (Menzel \& Simpson, 1995). When the culture is in hot climate and large rainfall areas, such as in Florida, USA, or in the mid-west region of the state of São Paulo, the trees have very vigorous vegetative outbreaks, every two or three months, to the detriment of blooming (Li \& Xiao, 2001).

Lychee production in hot climates is hampered by low flowering. However, there are technologies being tested that are shown as promising to induce flowering, and one of these is branch girdling. Irregular productions, which are associated with small flowering and low fruit fixation, are important problems of this crop in the world. Production alternation characteristic in different cultivars and climate order restrictions are the main causes related to flowering problems (Ghosh, 2001).

An alternative approach to the low flowering problem is primary or secondary branch girdling. There are references of girdling use in several lychee producing countries, and the technique involves making an incision from 1.6 to $4.0 \mathrm{~mm}$ wide, usually with the help of a pruning saw, in the whole branch circumference (Carvalho \& Salomão, 2000).

The lychee can be a production alternative in tropical regions as an option for market diversification, thus it is necessary to develop technologies that will enable its economic production to the hot climate regions in Brazil, highlighting the use of branch girdling.

Therefore, the objective was to evaluate the influence of branch girdling and of the girdled branches quadrant location in the plant canopy on lychee flowering in a tropical region.

\section{Material and methods}

The project was conducted in the municipality of Colatina - ES, located at coordinates $19^{\circ} 29^{\prime} 52.7^{\prime \prime S}$ and 4045'36.9"W . Girdling was carried out in two seasons (October 2010 and March 2011), and girdling was performed in October, a time characterized in the region to precede months with elevated air temperatures that are unfavorable to flowering, as a try to lychee extemporaneously production. As the girdling in October had not produced flowering induction, the experiment final analysis outlined in a randomized block design was done in a factorial $4 \times 4$ (branches $x$ quadrants) instead of $4 \times 4 \times 2$ ( branches $\times$ quadrants $\times$ periods), with four replications and one tree as experimental plot.

In every period the following girdlings were performed on individual plants, with these being nine years old: main branch girdling, with 8.0 to $10 \mathrm{~cm}$ in diameter; branch girdling with 6.0 to $7.9 \mathrm{~cm}$ in diameter, branch girdling from 4.0 to $5.9 \mathrm{~cm}$ in diameter, and control, without girdling.

Girdling was performed with a pruning saw, and the incision was about $2.5 \mathrm{~mm}$ wide and $2 \mathrm{~mm}$ deep. After the cuts were made, copper-based paste was applied in the girdling region as disease prevention. For the case of main branches or strides girdling, all present branches were girdled, which were around three, except for one or two branches that have the function to keep photoassimilates flow. Girdling in 4.0 to 5.9 and 6.0 to $7.9 \mathrm{~cm}$ in diameter branches were performed, respectively, on six and four branches per tree.

Assessed variables during three weeks in August 2011 were: inflorescence amount and inflorescence length per quadrant, (northeast (NE), Northwest (NW), Southeast (SE), southwest (SW)) and per tree, which were marked with GPS (Global Positioning System), with crop rows having east (E) and west (W) direction. Inflorescence amount was performed by counting inflorescences present in $1 \mathrm{~m}^{2}$ of quadrant; and 10 inflorescences per quadrant length was held in each quadrant with a millimeter ruler, without plants inflorescences withdrawal. For this, a ladder was used to reach these inflorescences in the canopy.

Flowering percentage was performed by counting the assessed quadrant's number of flowers in relation to all tree canopy quadrants within each treatment. To calculate the flowering percentage, all flowers from all four tree canopy quadrants were added, and each quadrant flowering percentage within each treatment was multiplied by 100 and divided by tree canopy quadrants total flower number. These assessments were related to the girdling period performed in March, as the October girdling had not stimulated flowering. To compare the girdling effect on flowering and inflorescence length, an area of $1 \mathrm{~m}^{2}$ per lychee canopy quadrant was assessed; for this, a $1 \mathrm{~m}^{2}$ wooden frame was placed at random in the upper third of each canopy quadrant was used. Lychee canopy quadrants orientations were: southwest and southeast (orientations that received less light), and northwest and northeast (orientations that received more light). This varying brightness receipt happened due to the sun's position, which in the southern hemisphere, during the period from girdling (March - autumn in the southern hemisphere) to assessment conduction (August winter in the southern hemisphere), the sun, in its apparent motion, gradually leans more to the north, 
providing a higher solar radiation incidence in plant quadrants more oriented to the north (less shaded northeast and northwest) and less incidence on those more oriented to the south (shadier - southeast and southwest).

Data were subjected to analysis of variance, and means were compared by Tukey's test, at $5 \%$ probability. Data were transformed by square root of $(X+1)$ expression for flowering amount, inflorescence length and flowering percentage variables.

\section{Results and discussion}

Girdling carried out in October 2010 had not flowered. This can be explained by the high temperatures in the subsequent months (Table 1).

Therefore, branch girdling with different diameters in periods that preceded high temperature months seemed to have no effect. Menzel \& Simpson (1995) found that temperatures lower than $15^{\circ} \mathrm{C}$, four to six weeks prior to flowering, are favorable to floral induction. The same authors state that temperatures above $20^{\circ} \mathrm{C}$ at the same period can inhibit the process. This seems to indicate that even with flowering stimulus by girdling technique, if the subsequent months are of very high temperatures, this technique may not be effective. Therefore, the use of girdling technique for extemporaneous blooming production in regions with average temperatures above $20^{\circ} \mathrm{C}$ does not seem to be a good alternative.

In this study, flower amount and inflorescence length variables showed reasonable homoscedasticity (equal variance between treatments), which was confirmed by Bartlett's test with $p$ values equal to 0.1006 and 0.4682 , respectively, at $5 \%$ significance.

Table 1 - Minimum ( $\min T$ ), maximum $(\max T$ ) and average (average T) monthly air temperatures from November 2010 to June 2011 in Colatina-ES, Brazil.

\begin{tabular}{lccc}
\hline Months & $\min \mathrm{T}\left({ }^{\circ} \mathrm{C}\right)$ & $\max \mathrm{T}\left({ }^{\circ} \mathrm{C}\right)$ & average $\mathrm{T}\left({ }^{\circ} \mathrm{C}\right)$ \\
\hline November & $20-22$ & $30-32$ & $24-26$ \\
December & $22-24$ & $32-34$ & $26-28$ \\
January & $22-24$ & $32-34$ & $26-28$ \\
February & $22-24$ & $>34$ & $26-28$ \\
March & $22-24$ & $30-32$ & $26-28$ \\
April & $20-22$ & $28-30$ & $24-26$ \\
May & $16-18$ & $28-30$ & $20-22$ \\
June & $16-18$ & $26-28$ & $20-22$ \\
\hline
\end{tabular}

Source: Brasil (2011).

Adjusted model residues were submitted to the Shapiro-Wilk normality test, which detected normality presence at $5 \%$ probability, justified by $p$ values equal to 0.09866 and 0.06523 , for flowers number and inflorescence length, respectively, and it may be concluded that data had normal distribution. Furthermore, the experiment showed a coefficient of variation of around $49 \%$, indicating poor accuracy thereof; therefore, data were re-scaled, i.e., transformed by the expression square root $(X+1)$ for all analyzed variables, what fixed the problem, reducing the CV to $3.54 \%, 3.30 \%$ and $4.86 \%$ for flowers number, inflorescence length and flowering percent, respectively. After data transformation, a preliminary analysis of variance was performed to analyze treatments effect. Thus, through $F$ test, it is concluded that at least one treatment differs from others $(p=0.00061)$ at $5 \%$ significance.

As flowering percentage normality assumptions violation occurred with transformed data, through Shapiro-Wilk test $(p=0.00043)$ and equal variance test $(p=0.000045)$, the nonparametric Kruskal-Wallis test was used. This test indicated that there were no significant difference between treatment effects $(p=0.7061)$.

Considering the factorial $(4 \times 4)$, the main girdling and quadrant factors effects were significant
( $p=0.000311$ and $p=0.00803$, respectively), in girdling conducted in March. However, there was no interaction between factor levels, indicating that girdling factor levels do not depend on quadrant factor levels and vice versa (Table 2). According to the analysis of variance for inflorescence number, it was shown that both assessed girdling and quadrants were significant, but there was no significant interaction between them (Table 2).

For inflorescence length, the (girdling $x$ quadrant) interaction was also not significant $(p=0.307)$, thus girdling effects on the average inflorescence length production in lychee plants occurs independently of quadrant location (or vice versa). For quadrants, the test was not significant $(p=0.789)$, therefore, they did not have different effects on the average inflorescence length per plant production (Table 3).

It was observed that in the months following the girdling carried out in March 2011, despite the temperature not dropping below $15^{\circ} \mathrm{C}$ (Table 1), there was lychee tree flowering with girdling use, and on branches from 6.0 to 7.9 and 8.0 to $10 \mathrm{~cm}$ diameter, the inflorescence amount was significantly higher $(p<0.05)$ than in the branches from 4.0 to 5.9 $\mathrm{cm}$ in diameter and in control branches, which were without girdling (Table 4). This indicates that for hot 
climates, which do not have satisfactory climatic conditions for lychee cultivation, the branches from 6.0 to $10 \mathrm{~cm}$ in diameter are the ones to be chosen to perform the girdling, in order to increase produced inflorescences number. This result extends the regions with this fruit growing viability in the harvest period.

Table 2 - Variance analysis of data transformed by the expression square root of $(X+1)$ for the variable inflorescence amount.

\begin{tabular}{lccccc}
\hline Variation Factor & DF & SS & MS & F & $\operatorname{Pr}(>\mathrm{F})$ \\
\hline Girdling (Treat.) & 3 & 2.926 & 0.9753 & 7.5464 & $0.000311^{* * *}$ \\
Quadrant (Quad) & 3 & 1.712 & 0.5707 & 4.416 & $0.008039^{* *}$ \\
Treat x Quad. & 9 & 0.809 & 0.0899 & 0.696 & $0.0709416^{\text {ns }}$ \\
Residues & 48 & 6.204 & 0.1293 & - & - \\
\hline Total & 63 & 11.65 & 1.7652 & - & - \\
\hline
\end{tabular}

DF - Degree of freedom; SS - Squares sum ; MS - Mean square; F - F value; Pr - Probability; ${ }^{* * *}$ - Significant at $0.01 \%$ probability by $\mathrm{F}$ test; ${ }^{* \star}$ - Significant at $0.1 \%$ probability by $\mathrm{F}$ test; ${ }^{\text {ns }}$ Not significant at $5 \%$ probability by $\mathrm{F}$ test.

Table 3 - Variance analysis of data transformed by the expression square root of $(X+1)$ for the variable inflorescence length.

\begin{tabular}{lccccc}
\hline Variation Factor & DF & SS & MS & F & $\operatorname{Pr}(>\mathrm{F})$ \\
\hline Girdling (Treat.) & 3 & 0.0004211 & $1.404 \times 10^{-04}$ & 12.814 & $2.83 \times 10^{-06 * * *}$ \\
Quadrant (Quad) & 3 & 0.0000115 & $3.840 \times 10^{-06}$ & 0.307 & $0.789 \mathrm{~ns}$ \\
Treat x Quad. & 9 & 0.0001201 & $1.334 \times 10^{-05}$ & 1.218 & $0.307 \mathrm{~ns}$ \\
Residues & 48 & 0.0005258 & $1.095 \times 10^{-05}$ & - & - \\
\hline Total & 63 & 0.0010785 & $1.685 \times 10^{-04}$ & - & - \\
\hline
\end{tabular}

DF - Degree of freedom; SS - Squares sum ; MS - Mean square; F - F value; Pr - Probability; ${ }^{* \star \star}$ - Significant at $0.01 \%$ probability by $\mathrm{F}$ test; ${ }^{\text {ns }}$ Not significant at $5 \%$ probability by $\mathrm{F}$ test.

Table 4 -Inflorescences amount, flowering percentage and Inflorescences length in light of the diameter branches that were girdled in March 2011 (DRA) and the location of the branches girdled in the lychee canopy (Quadrants - Quad.). Colatina-ES, Brazil.

\begin{tabular}{|c|c|c|c|c|c|c|c|c|c|c|c|}
\hline \multicolumn{4}{|c|}{ (1)Inflorescences amount (units) } & \multicolumn{4}{|c|}{ (1)Flowering percentage } & \multicolumn{4}{|c|}{ (1)Inflorescences length (cm) } \\
\hline DRA (cm) & ${ }^{(2)}$ Mean & ${ }^{(3)}$ Quad. & (2)Mean & DRA (cm) & (2)Mean & ${ }^{(3)}$ Quad. & (2)Mean & DRA (cm) & (2)Mean & ${ }^{(3)}$ Quad. & (2)Mean \\
\hline 8.0 to 10.0 & $21.9 \mathrm{~A}$ & SW & $18.9 \mathrm{AB}$ & 8.0 to 10.0 & $25.0 \mathrm{~A}$ & sW & $32.0 \mathrm{~A}$ & 8.0 to 10.0 & $16.6 \mathrm{~A}$ & sW & $13.5 \mathrm{~A}$ \\
\hline 6.0 to 7.9 & $21.1 \mathrm{~A}$ & $\mathrm{~s}$ & $19.6 \mathrm{~A}$ & 6.0 to 7.9 & $24.9 \mathrm{~A}$ & 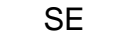 & $34.8 \mathrm{~A}$ & 6.0 to 7.9 & $16.3 \mathrm{~A}$ & . & $12.9 \mathrm{~A}$ \\
\hline 4.0 to 5.9 & $11.4 \mathrm{~B}$ & NW & $13.2 \mathrm{~B}$ & 4.0 to 5.9 & $24.9 \mathrm{~A}$ & NW & $16.0 \mathrm{~B}$ & 4.0 to 5.9 & $9.2 \mathrm{~B}$ & NW & $10.5 \mathrm{~A}$ \\
\hline (4)Control & $11.0 \mathrm{~B}$ & NE & $13.5 \mathrm{~B}$ & (4)Control & $24.9 A$ & NE & $16.8 \mathrm{~B}$ & (4)Control & $5.6 \mathrm{~B}$ & NE & $10.8 \mathrm{~A}$ \\
\hline${ }^{(5)} \mathrm{CV}(\%)$ & 3.44 & $\mathrm{~V}(\%)$ & 3.68 & ${ }^{(5)} \mathrm{CV}(\%)$ & 6.04 & $\mathrm{CV}(\%)$ & 5.41 & ${ }^{(5)} \mathrm{CV}(\%)$ & 2.89 & ${ }^{5)} \mathrm{CV}($ & 3.60 \\
\hline
\end{tabular}

(1) Original values; Statistical analysis performed on the transformed data by $(X+1)$ square root. ${ }^{(2)}$ Means followed by the same capital letter in the column do not differ by Tukey test at $5 \%$ probability; (3) SW - Southwest, SE - Southeast, NW Northwest, NE - Northeast; ${ }^{(4)}$ Control - Branches without girdling; ${ }^{(5)}$ Coefficient of variation.

Considering quadrants overall mean for each girdled branch diameter range, branch girdling in diameters between 6.0 and $10.0 \mathrm{~cm}$ induced significantly higher inflorescence amounts $(p<0.05)$ than in the branches with diameters from 4.0 to $5.9 \mathrm{~cm}$ and branches without girdling (control) (Table 4).

On average, that is, considering the plant canopy as a whole, girdling has not influenced the average flowering percentage (Table 4).

On the overall mean of girdled and not girdled (control) branches, it appears that in the most shaded quadrants (southeast and southwest), flowering percentage was significantly higher $(p<0.05)$ than in the quadrants that received more light (northeast and northwest) (Table 4).

On the general mean, regardless of branch diameter, branch position in the canopy quadrants produced no significant differences $(p>0.05)$ in inflorescence length (Table 4).

On the overall mean of quadrants within each girdled branch's diameter, it was found that larger diameters, between 6.0 and $10.0 \mathrm{~cm}$, branch girdling resulted in significantly longer inflorescences $(p<0.05)$ than the ones produced by girdling branches 4.0 to 5.9 $\mathrm{cm}$ in diameter and those produced by non-girdled branches (control) (Table 4).

\section{Conclusions}

In order to enhance lychee insertion in hot climate regions, like Colatina-ES, and seeking to increase inflorescence production using the branch girdling technique, it was concluded that:

Extemporaneous lychee production attempt 
based on branch girdling in October, in Colatina-ES, was not feasible because flowering induction did not occur, regardless of diameter and the plant canopy quadrant in which they are located;

Branch girdling in March was the most advantageous technique, and it is recommended to be used in all plant canopy quadrants, and only in branches with diameters from 6 to $10 \mathrm{~cm}$. In branches with smaller diameters than these, in any canopy quadrant, branch girdling technique was not advantageous.

\section{References}

Brasil (2011) Ministério da Ciência, Tecnologia e Inovação. Centro de Previsão de Tempo e Estudos Climáticos (CPTEC). Available at: < http://www.cptec.inpe.br/agricultura.gov.br>. (accessed: 13 nov. 2011).

Carvalho CM, Salomão CC (2000) Cultura da lichieira. Viçosa: Universidade Federal de Viçosa. 38p. (Boletim de extensão, 43).
García-Pérez E, Martins ABG (2006) Florescimento e frutificação de lichieiras em função do anelamento de ramos. Revista Brasileira de Fruticultura 28(1):14-17.

Ghosh SP (2001) Word trade in litchi: past, present and future. Acta Hoticulturae 558(1):23-30.

Li CH, Xiao Y (2001) A Girdling increases yield of 'Nuomici' litchi'. Acta Horticulturae 558(34):233-235.

Martins ABG (2005) Lichia Revista Brasileira de Fruticultura 27(3):95-97.

Menzel CM, Simpson DR (1995) Temperatures above $20^{\circ} \mathrm{C}$ reduce flowering in lychee (Litchi chinensis Sonn). The Journal of Horticultural Science \& Biotechnology 70(6):981-988.

Zhang Z, Pang X, Ji Z, Jiang Y (2001) Role of anthocyanin degradation in litchi pericarp browning. Food Chemistry 75(1):217-221.

Zhang Z, Xuenqun P, Yqng C, JI Z, Jing Y (2004). Purification and structural analysis of anthocyanins from litchi pericarp. Food Chemistry 84(4):601-604. 